\title{
Mirosław Górecki
}

Wydział Stosowanych Nauk Społecznych i Resocjalizacji, Uniwersytet Warszawski

E-mail: mgorec@uw.edu.pl

ORCID: 0000-0002-8988-5006

\section{Życie emocjonalne i seksualne ludzi starych****}

\section{Summary}

\section{THE EMOTIONAL AND SEX LIFE OF THE ELDERLY***}

The gradual decline of the sexual performance of the elderly does not imply that their erotic needs extinguish completely. Only the possibilities and the means to obtain satisfaction change. The article presents the erotic aspects of the functioning of elderly people. It focuses primarily on the breakdown and on the reconstruction of senior marriages, the responses to these situations by close relatives, on informal relationships, on the reasons of reduced sexual activity of the elderly or even their sexual abstinence and on the functions of sex at old age. An important issue is the need to disseminate the knowledge on sexuality of the elderly and to promote more accepting attitudes towards their sexuality.

Key words: elderly, sexual activity, divorce, marriage, informal relationships

red. Paulina Marchlik

\section{Wprowadzenie}

Seksualność stanowi jeden z najważniejszych elementów ludzkiej egzystencji. Wiążą się z nią wartości, które najbardziej cenimy: miłość, szczęście, radość, spełnienie, poczucie bezpieczeństwa, jedności i akceptacji. Aktywność seksualna zapewnia zachowanie dobrego zdrowia fizycznego i psychicznego.

\footnotetext{
* ul. Podchorążych 20, 00-721 Warszawa

粎 Finansowanie: Uniwersytet Warszawski
} 
Często jednak staje się przyczyną rozmaitych problemów w relacjach interpersonalnych czy problemów z samym sobą. Może więc budować, ale i niszczyć życie każdego człowieka oraz niweczyć jego plany. W ostatnich latach ukazało się wiele publikacji na temat starości i losu osób starych, natomiast niewiele z nich porusza zagadnienie ich zachowań seksualnych.

Ani menopauza ${ }^{1}$ u kobiet, ani andropauza ${ }^{2}$ u mężczyzn nie są granicą możliwości seksualnych człowieka. Powszechnie sądzi się, że menopauza i andropauza to dwa różne określenia tych samych procesów somatyczno-psychicznych, a mianowicie przekwitania i starzenia się. Jednak u mężczyzn wraz z nadejściem andropauzy nie zachodzą nagłe i odczuwalne zmiany, ponieważ średnie stężenie testosteronu w surowicy krwi obniża się z wiekiem bardzo wolno - mniej więcej o 1\% rocznie (poziom hormonu płodności u mężczyzny, mającego 80 lat to $60 \%$ wartości, jakie występują w wieku 20-40 lat), tylko u około $30 \%$ mężczyzn po 60. roku życia zmniejsza się liczba plemników, co nie oznacza niepłodności ani obniżenia ich jakości (Dębski, 2014). Amerykańscy seksuolodzy, Sandra Leiblum i Taylor Segraves podkreślają, że „u zdrowych mężczyzn sam wiek nie jest czynnikiem, który ogranicza zdolność do penetracji. Część z nich pozostaje aktywna seksualnie po osiemdziesiątym czy nawet dziewięćdziesiątym roku życia, choć w takim wypadku częstotliwość współżycia jest mniejsza niż u czterdziesto- czy pięćdziesięciolatka. Należy również pamiętać, że wpływ wieku na seksualność jest sprawą indywidualną. Podczas gdy większość siedemdziesięciolatków odbywa stosunki koitalne średnio raz w tygodniu lub rzadziej, są i tacy, którzy robią to trzy razy w tygodniu, a nawet częściej. Nie należy zakładać, że zaawansowany wiek oznacza zmniejszenie aktywności seksualnej” (Leiblum, Segraves, 2005, s. 502).

Polski neurolog Jerzy Vetulani powołując się na amerykańskie badania pisze: „Aktywność seksualna mierzona liczbą stosunków w ciągu miesiąca spada, mimo to u osób 80 plus jeszcze $24 \%$ mężczyzn i 18-20\% kobiet utrzymuje swoją aktywność seksualną na poziomie dwóch stosunków w miesiącu” (Vetulani,

\footnotetext{
${ }^{1}$ Pojęcie menopauza oznacza koniec miesiączkowania, zakończenie okresu reprodukcji w życiu kobiety. Jest ona poprzedzona wcześniejszym okresem, a mianowicie klimakterium, które określa się jako stopniowy zanik czynności jajników. Te dwa terminy są często błędnie utożsamiane, traktowane jako synonimy.

${ }^{2}$ Termin andropauza to okres w życiu mężczyzny (najczęściej po 50. roku życia), zapowiadający zbliżające się wejście $\mathrm{w}$ fazę starości i z początkiem wystąpienia wielu dolegliwości w różnych sferach funkcjonowania jednostki, zarówno somatycznej, psychologicznej, jak i seksualnej o podłożu wielonarządowych zmian w organizmie, w tym także zmian hormonalnych, wywołanych starzeniem się.
} 
2015, s. 35). Natomiast Marcin Muszyński przestrzega: „U]eśli osoba w trzecim wieku spodziewa się, że jej ciało będzie reagowało w podobny sposób, tak jak za młodych lat, to z całą pewnością doświadczenie to okaże się dla niej frustrujące i będzie przyczyną niezadowolenia. Kiedy jednak człowiek nauczy się akceptować fakt bycia starym i zaadaptuje się do zmian zachodzących w ciele, seks może okazać się satysfakcjonujący. Seks dla młodych jest szybki i gwałtowny. Starsi muszą dorosnąć do bardziej wysublimowanych i wyrafinowanych sposobów życia seksualnego i znaleźć nową perspektywę seksualnego zadowolenia. Może on wzbogacić różne wymiary doświadczenia, a także kompensować różnego rodzaju niedostatki osób starszych" (Muszyński, 2007, s. 125).

Zdaniem Zbigniewa Lwa-Starowicza zdarzają się paradoksalne zjawiska, a mianowicie „dopiero $\mathrm{w}$ jesieni życia pojawia się wzrost zainteresowania seksem, kiedy pogoń za sukcesami zawodowymi czy zaabsorbowanie życiem rodzinnym zmniejsza się na rzecz większego zainteresowania sobą samym" (Lew-Starowicz, 2004, s. 17). Natomiast Andrzej Jaczewski przestrzega, że „należy zaakceptować i przyjąć do wiadomości potrzeby seksualne ludzi starych. Jakość życia na starość często zależy od tego. Powinni wiedzieć o tym sami zainteresowani (czyli ludzie starzy), jak też ich rodziny i opiekunowie" (Jaczewski, 2006, s. 41).

Biorąc pod uwagę przytoczone tu główne konstatacje dotyczące seksualności ludzi starych wydaje się celowe przedstawienie, jak uzewnętrznia się i jak jest organizowane pożycie seksualne tej grupy osób. Opracowanie to ma charakter przeglądowy, oparty na wynikach dotychczasowych badań psychospołecznych. Ich analiza przeprowadzona jest pod kątem form ekspresji i sytuacji życiowych, w których interakcje te zachodzą. Jeśli chodzi o formy ekspresji to najogólniej rzecz biorąc przybierają one trojaką postać: albo samozaspokojenia albo wyłącznie wymiany emocjonalnej z wyraźnym zabarwieniem erotycznym, albo stosunku koitalnego. Dlatego też $w$ tytule użyto sformułowania życie emocjonalne różniące się istotnie od form łączących emocjonalność z pełnym aktem seksualnym. Natomiast aspekt sytuacyjny określa warunki, w których interakcje te zachodzą: samotność, konkubinat bez kohabitacji oraz konkubinat i małżeństwo oparte na prowadzeniu wspólnego gospodarstwa. Pod względem podmiotowym analizą tą objęto zachowania seksualne ludzi starych poprzestając na ich ogólnym określeniu, mimo że w gerontologii przyjmuje się ich dość ścisłe kategoryzacje na osoby w wieku podeszłym, starczym i sędziwym. $\mathrm{Z}$ jednej strony uzasadniają to założenia metodologiczne relacjonowanych badań, które prowadzone były często na populacjach obejmujących osoby już po 
50. roku życia, z drugiej zaś przytoczone wyżej stwierdzenia, że aktywność seksualna i formy jej ekspresji zależą nie tyle od wieku metrykalnego, ile od stanu sił witalnych.

\section{Rozpad i rekonstrukcja związków małżeńskich seniorów}

W okresie starości oprócz opisanych zmian w sferze fizjologicznej mogą zachodzić również zmiany o charakterze społecznym, których podłoże przeważnie wiąże się z erotycznymi aspektami funkcjonowania człowieka. Ich widocznym wyrazem są rozwody i śluby, a także reakcje na te sytuacje osób najbliższych. Jedną z przyczyn rozpadu związku jest śmierć współmałżonka/ partnera. Taka strata jest często faktem bardzo trudnym do zaakceptowania i pogodzenia się z jego konsekwencjami. Pociąga ona za sobą szczególnie dramatyczne przeżycia, zwłaszcza gdy rozstanie przerywa więzi osnute na miłości i wiąże się z ciężką, śmiertelną chorobą i cierpieniem. Uczucie wielkiej miłości i bezgranicznego oddania skłania do zaspokojenia wszystkich potrzeb osoby umierającej, zapewnienia jej komfortu i wyciszenia emocji. Wtedy żałoba trwa przez długi okres czasu oraz wywołuje traumatyczne i bolesne reakcje psychiczne. „Owdowiała osoba - pisze Piotr Szukalski - musi sobie poradzić z samodzielnym gospodarowaniem (zadanie trudne dla kobiet głównie ze względów materialnych, zaś w wyniku «kulturowo» ukształtowanego nieprzystosowania do wykonywania niektórych prac domowych - dla mężczyzn), brakiem wsparcia psychicznego, brakiem najbliższego opiekuna w przypadku choroby, a wreszcie z samotnością i osamotnieniem" (Szukalski, 2006, s. 68). Uczucie samotności może spowodować stopniowe wycofywanie się z życia społecznego, a w konsekwencji doprowadzić do zupełnego wyizolowania się.

Rozpad związku następuje także w wyniku wzajemnego znudzenia, utraty atrakcyjności, niesatysfakcjonującego współżycia seksualnego, narastającej niechęci, zdrady, nierozwiązanych sytuacji kryzysowych. Decyzję o rozstaniu może też przyspieszać zmiana sytuacji życiowej. Po przejściu na emeryturę i opuszczeniu przez dzieci domu rodzinnego, gdy codzienny harmonogram zadań zawęża się, spora liczba osób starych dochodzi do wniosku, że nie widzą powodu, by nadal mieszkać pod wspólnym dachem lub nie może dłużej już znieść towarzystwa żony/męża. Stają w obliczu życiowej próżni. Przyzwyczajenia czy wady współmałżonka, dawniej przebaczane i traktowane $\mathrm{z}$ pewną czułością, z czasem okazują się nieznośne. Ludzie starzy z dużym stażem małżeńskim już 
nie tyle „nie chcą”, ile „nie potrafią” żyć razem. I nie tyle „w związku”, ile z „tą osobą”. Młodsze małżeństwa spajają jeszcze wzajemne uczucia, w starszych natomiast dominują zniechęcenie i ogólna rezygnacja.

Utrata współmałżonka/partnera, zarówno z powodu śmierci, jak i rozwodu, powoduje określone negatywne skutki fizyczne i psychiczne. Mężczyźni bardziej niż kobiety przeżywają utratę partnera, bo mają większe trudności z organizacją życia codziennego (Podogrodzka, 1992, s. 58). Po śmierci jednego z małżonków/partnerów ryzyko zgonu drugiego znacznie wzrasta, zwłaszcza pierwszy rok po tej utracie staje się szczególnie niebezpieczny pod tym względem. Wynika to z konieczności przystosowania się do nowo zaistniałej sytuacji (Kaprio i in., 1987, s. 283-287; Szukalski, 2006, s. 68; Podogrodzka, 1992, s. 58). Rozwód bywa często przyczyną nadużywania alkoholu, stosowania przemocy, problemów zdrowotnych, a nawet samobójstw. W literaturze amerykańskiej zwraca się także uwagę na korelację między długoletnim pożyciem a zapadalnością na poważne choroby somatyczne (Goodwin i in., 1987, s. 3125-3130). Nawet związki nieformalne coraz śmielej zastępujące małżeństwo, wywierają równie korzystny wpływ na stan zdrowia i poziom umieralności osób pozostających w tych związkach. Zależność ta jest odnoszona tylko do związków kohabitacyjnych, gdyż „w przypadku związków typu LAT $^{3}$ można mieć uzasadnione wątpliwości $\mathrm{z}$ uwagi na zbyt "otwarty» charakter relacji i zdecydowanie mniejsze możliwości wpływu partnerów na swe zachowania" (Szukalski, 2007, s. 43).

W Polsce od dwóch dekad liczba rozwodów osób starych systematycznie rośnie. Ta tendencja jest widoczna w całym naszym kraju, szczególnie w miastach, gdzie społeczne przyzwolenie na rozwód jest zdecydowanie większe. Według Rocznika Demograficznego 2019 w Polsce w 2018 r. rozwody orzeczono wobec 4362 mężczyzn $(6,9 \%)$ w wieku 60 lat i więcej, w tym 3384 osób (7,5\%) mieszkających w mieście, a $954(5,7 \%)$ - na wsi, zaś kobiet w wieku 60 lat i więcej - 2608 (4,2\%), w tym 2076 osób (4,6\%) mieszkających w mieście, a $522(3,1 \%)$ - na wsi (Rocznik Demograficzny 2019, s. 246). „Zaczynamy rozumieć - pisze Aleksandra Żelazińska - to, o czym od dawna przekonują psychologowie - dzieci nie scementują związku na wieczność. W atmosferze przynajmniej częściowej społecznej aprobaty decyzję o rozwodzie łatwiej podjąć niż kiedyś. A jeśli już pęka społeczne tabu, następni będą coraz częściej wybierać tę ścieżkę wyjścia $\mathrm{z}$ niekomfortowej sytuacji. [...] Dziś szczytem

${ }^{3}$ Związki łączące osoby prowadzące odrębne gospodarstwa domowe (Living Apart Together LAT). 
heroizmu nie jest trwanie w małżeństwie za wszelką cenę, ale zakończenie go, zanim będzie za późno albo zbyt niebezpiecznie" (Żelazińska, 2015, s. 21).

Nie mniejsze emocje niż rozwody wzbudzają śluby ludzi starych. Kryje się za tym brak rozumienia przez ich dzieci motywów zawarcia przez nich związku małżeńskiego. Nie wierzą one już, że w takim wieku można się zakochać, nie rozumieją do czego ich starym rodzicom jest potrzebny partner/ partnerka. Można usłyszeć od nich takie opinie: „Porządna wdowa całe życie powinna być w żałobie”, „Matce zachciewa się odgrywać Julię na emeryturze, ojcu Romea” (Czupryn, 2008). Z drugiej strony w takiej sytuacji często objawia się pragmatyczne podejście do życia dorosłych już dzieci. Obawiają się, że nowy małżonek może chcieć odebrać majątek ich matce lub ojcu (obawa ta rośnie gdy jeden z partnerów jest dużo młodszy) oraz, że ich rodzic, który skupi się na partnerze nie będzie im pomagać, np. przy opiece nad ich dziećmi.

Wchodzenie w nowy związek po śmierci współmałżonka spotyka się z dwoma reakcjami najbliższej rodziny. Dla jednych powtórny związek rodzica jest przyjmowany z akceptacją, zrozumieniem, a niekiedy dużą ulgą, iż obowiązek wspierania czy sprawowania opieki nie będzie spoczywać wyłącznie na rodzinie. Natomiast dla drugich wywołuje negatywne odczucia, szczególnie jeśli odbierany jest jako zdrada pamięci zmarłego, z którym byli mocno związani. Dość często też zdarzają się sytuacje, potwierdzające słuszność obaw dzieci przed wykorzystywaniem ich rodziców przez nowego partnera na tle majątkowym.

Młodzi, a często nawet niektórzy starzy uważają, że w późnym wieku zakochać się nie można, że miłość jest wtedy raczej karykaturą tego, co czuło się będąc młodym. Przekonanie to czynią czymś niepodważalnym i nieczułym na takie historie i pełne uczuć wypowiedzi, jak np. ta: „Spotkałem kobietę, która tak mocno przypadła mi do serca, że świat nabrał dla mnie nowych barw. Uczucia, które dotąd żywiłem do innych kobiet, wydały mi się powierzchowne, związane niemal wyłącznie z seksem. Dopiero teraz, gdy dożywam 70. roku życia, wiem, czym jest prawdziwa miłość i na czym polega jej bogactwo" (Pietkiewicz, 2008, s. 84).

Osoby stare decydują się na ponowny ślub, bo szukają pomocy w codziennych czynnościach i wsparcia w przypadku choroby, a także chcą jeszcze coś w życiu przeżyć i czegoś doświadczyć. Śmierć dotychczasowego partnera lub rozwód wywołują nie tylko pustkę po utracie towarzysza życia, ale także zazwyczaj ograniczenie kontaktów interpersonalnych. Chcąc uniknąć samotności szukają kolejnego współmałżonka/partnera. Ze względu na przywiązanie do tradycji opartej na religii i wpływ najbliższego środowiska rzadko wybierają życie w konkubinacie. Na podjęcie decyzji o zawarciu małżeństwa wpływ 
mają również czynniki materialne. Wszak po utracie partnera wzrost obciążeń finansowych, wynikających z konieczności pokrywania w pojedynkę kosztów utrzymania mieszkania i codziennego życia, zmusza często do zawarcia ponownego związku małżeńskiego.

Dorota Kałuża dokonała analizy małżeństw osób po 60. roku życia na podstawie danych Głównego Urzędu Statystycznego z lat 1970-2008. Nowożeńcy w tym wieku stanowili około 3\% wszystkich małżeństw w Polsce. Najczęściej te związki były tworzone przez osoby owdowiałe. Na małżeństwo zdecydowanie częściej decydowali się mężczyźni (blisko 70\%) niż kobiety. Ta wartość była stabilna w całym analizowanym okresie. Według danych z 2008 r. wynika:

- na 100 kobiet w wieku 60 lat zawierających małżeństwo przypadało 187 mężczyzn w tej grupie wieku, zaś w wieku 85 lat i więcej - już 655;

- osoby w wieku 60 lat i więcej podejmowały następujące wybory: wdowcy szukali najczęściej wdów, rozwiedzeni - rozwiedzionych, stare panny wolały wdowców niż starych kawalerów i rozwodników, natomiast tylko kawalerowie wybierali panny, wdowy lub rozwiedzione;

- $\quad$ na śluby częściej decydowały się osoby z miast niż ze wsi;

- $\quad$ związki małżeńskie zawierały najczęściej osoby mieszkające na obszarach północno-zachodnich, a najrzadziej - $\mathrm{z}$ województw ściany wschodniej (Kałużna, 2010, s. 289-304).

Według Rocznika Demograficznego 2019 w Polsce w 2018 r. związek małżeński zawarło 5920 mężczyzn $(3,1 \%)$ w wieku 60 lat i więcej, w tym 4513 osób $(3,9 \%)$ mieszkających w mieście, a $1407(1,8 \%)$ - na wsi (Rocznik Demograficzny 2019, s. 185), zaś kobiet w wieku 60 lat i więcej - 3437 (1,8\%), w tym 2672 osób (2,3\%) mieszkających w mieście, a $765(1,0 \%)$ - na wsi (Rocznik Demograficzny 2019, s. 186).

\section{Związki nieformalne osób starych}

W literaturze przedmiotu wymienia się co najmniej dwa rodzaje tego typu związków: związki kohabitacyjne i związki partnerskie, łączące osoby prowadzące odrębne gospodarstwa domowe (typ LAT).

W związkach kohabitacyjnych dwie niespokrewnione dorosłe osoby wspólnie zamieszkują, utrzymują kontakty intymne i prowadzą wspólne gospodarstwo domowe. Osoby wchodzące w takie związki zachowują względną niezależność, 
co polega na tym, że jednak łączy ich trwałe zaangażowanie emocjonalne i odczuwanie satysfakcji ze współbycia, a więc przede wszystkim czerpanie z niego poczucia bezpieczeństwa oraz wspólnego przeżywania trosk i radości życia.

Powody wchodzenia w te związki są rozmaite:

- niechęć jednego lub dwojga partnerów do zawarcia formalnego małżeństwa $\mathrm{z}$ tradycyjnym podziałem ról w zależności od płci (mężczyzna odpowiedzialny za sytuację materialną, a kobieta za wychowywanie dzieci i prowadzenie domu $)^{4}$;

- chęć poznania i sprawdzenia się, czy możliwe jest bycie razem („związek na próbę", w którym testuje się siłę uczucia, zgodność charakterów i temperamentów przed podjęciem trwałego zobowiązania i związaniem się na resztę życia albo podejmuje się decyzję o rozstaniu się w przypadku pojawienia się znaczących niezgodności między partnerami. Jest on preferowany szczególnie przez te osoby, które mają już doświadczenia nieudanego małżeństwa);

- $\quad$ wzrost społecznej akceptacji kohabitacji ze względu na zmianę norm, postaw i zachowań w duchu liberalizmu i indywidualizmu;

- zachowanie nieograniczonej wolności osobistej i życie bez trwałych zobowiązań;

- oczekiwanie na rozwód z poprzednim partnerem/partnerką;

- łatwość przekształcenia tego związku w zalegalizowane małżeństwo w przypadku zaistnienia ważnej potrzeby.

Badacze węgierscy, Marietta Pongrácz i Zsolt Spéder, wyróżnili dwa rodzaje związków kohabitacyjnych (ze względu na stan cywilny osób je budujących) „stary typ” i „nowy typ”. Pierwszy „tworzą związki skupiające przynajmniej jedną osobę rozwiedzioną, separowaną lub owdowiałą, tj. jednostki, w przypadku których: przepisy prawa, złe wspomnienia i doświadczenia, przemawiają za pozostawaniem w niezalegalizowanym związku”. Drugi - „tworzą pary osób, które nigdy nie zawarły związku małżeńskiego, tj. w przypadku których, brak jest innych przeciwwskazań, jak te o charakterze czysto mentalnym (a zapewne również i ekonomicznym) przemawiających przeciwko legalizacji związku" (Pongrácz, Spéder, 2003, cyt. za: Szukalski, 2004, s. 55).

Tomasz Szlendak wymienił kohabitację przyjacielską, w której dwie osoby (jednej lub dwojga płci) mieszkają razem i tworzą wspólne gospodarstwo domowe. Nie chcą angażować się w związek o charakterze seksualnym, tylko

${ }^{4}$ Obecnie preferowane są związki oparte na partnerstwie, kompromisach, w których wzajemne oczekiwania podlegają negocjacjom, a nie przyjętym społecznie regułom. 
przyjacielskim. Decydują się na wspólne zamieszkanie, bo nie chcą być sami, dobrze im się ze sobą mieszka, zgadzają się w wielu istotnych kwestiach życiowych i odnoszą obopólne satysfakcje i korzyści. Zazwyczaj są to dwie kobiety (bądź więcej), nie mające ochoty na życie z mężczyznami, którzy prowadzą całkiem inny styl życia i mają odmienny stosunek do porządku czy estetyki (Szlendak, 2011, s. 486).

Natomiast związki partnerskie oparte są również na zabarwionej erotycznie więzi uczuciowej, ale z zachowaniem własnych podstaw egzystencji, osobnego mieszkania i niezależności materialnej. Są one najczęściej podyktowane ograniczeniami prawnymi, jak na przykład formalne trwanie faktycznie wygasłego związku małżeńskiego, zachowanie nabytych uprawnień socjalnych i rentowych, a także sprzeciwem dzieci wobec zaburzenia więzi rodzinnych. Decyzje przesądzające o takiej formie związku, mogą wynikać także ze szczególnej sytuacji zawodowej, która wymaga zamieszkania $\mathrm{w}$ innych miastach czy państwach, uwarunkowań środowiskowych, skłaniających do zachowania w dyskrecji na nowo ułożonego życia intymnego, przekonania, że utrzymanie pewnego dystansu sprzyja intensyfikacji uczuć. Znaczącą rolę może odgrywać w tych grupach wiekowych przyzwyczajenie i zadowolenie ze swojego położenia i współwystępująca $z$ tym niechęć do radykalnej zmiany lub obawa przed ryzykiem chybionego wyboru. Aczkolwiek zrębem tych związków jest potrzeba wzajemnej emocjonalnej zależności, to przecież choćby ze względów biologicznych namiętność jest w nich zazwyczaj przesunięta na drugi plan. W warstwie motywacyjnej zaś wysuwa się na plan pierwszy dążenie do łagodzenia przykrych skutków samotności czy chęć bycia potrzebnym.

Zapewne występujący obecnie wzrost liczby rozwodów, w tym i tych wśród par z długim stażem (Szukalski, 2013, s. 122), przełoży się na wzrost związków formowanych przez osoby stare w przyszłości. Za wzrostem liczby takich związków „przemawiać będzie zmieniający się na naszych oczach wzorzec wczesnej i późnej starości, coraz bardziej widzący w tych fazach życia nie czas przygotowywania się na śmierć, lecz czas korzystania z życia, co najwyżej w dostosowany do możliwości sposób. Zdecydowanie mniej pewne jest, jaką formę owe związki przyjmą" (Szukalski, 2014, s. 150). Obecnie już nie tak krytycznie ocenia się związki nieformalne, ale także i osoby stare nie widzą nic złego w ich tworzeniu, bo „w ciągu raptem ćwierćwiecza w Polsce dokonała się "cicha rewolucja» w sferze wzorców życia małżeńsko-rodzinnego" (Szukalski, 2014, s. 146). 


\section{Aktywność seksualna seniorów}

Miłość dwojga ludzi może mieć różne formy, ale wielu badaczy proponowało wprowadzenie podstawowego podziału na miłość namiętną i przyjacielską. Elaine Hatfield i Richard L. Rapson określili miłość namiętnq̨ jako „stan intensywnego pragnienia, aby zjednoczyć się z drugą osobą”, tożsamą z pożądaniem seksualnym, zaś miłość przyjacielskq jako „sympatię i czułość w stosunku do osób, z którymi związane jest nasze życie” (Hatfield, Rapson, 1996, s. 3). Miłość przyjacielska oznacza również wzajemne przywiązanie, zaufanie, chęć pomagania i otrzymywania pomocy. Jest ona pozbawiona namiętności, ale charakteryzuje się wysokim poziomem intymności i zaangażowania. „W szczęśliwych małżeństwach wraz z upływem lat nasila się więź uczuciowa, pogłębia wzajemne zaufanie, zwiększa liczba wspólnych spraw oraz wzajemna akceptacja" (Chmura-Rutkowska, Ostrouch, 2007, s. 192).

Badaczom zajmującym się tą problematyką jest znane zjawisko tak zwanej drugiej młodości lub kryzysu wieku średniego, które zwłaszcza dotyczy mężczyzn po 50. roku życia, ale może występować także znacznie później (kobietom również zdarzają się gwałtowne zakochania i szybkie podejmowanie decyzji). Przyczyną tego zjawiska jest świadomość „przełomu życiowego półmetka” i próba dokonania bilansu życia - zrealizowanych i niespełnionych planów. Zmianie ulega cały styl życia, często ma miejsce romans $\mathrm{z}$ o wiele młodszą partnerką, który może przeobrazić się w nowy związek i dochodzi do rozwiązania dotychczasowego małżeństwa, albo zdarza się, że wszelkie problemy związane z drugą młodością mężczyzny z czasem zanikają, a małżeństwo przeżywa swój renesans.

Zjawisko drugiej młodości jest sposobem obrony przed starzeniem się, podkreśleniem własnej atrakcyjności i sprawności. Wiąże się również z poczuciem, że „[... świat nadal stoi przed nim otworem, że jeszcze wszystko można w życiu zmienić i wiele osiągnąć. Dowodem na to bywa zdobycie nowej, zwykle młodej partnerki. [...] Kiedy mężczyzna przeżywa niepokój związany z własnym starzeniem się, ma poczucie, że nadszedł ostatni moment, aby coś jeszcze mogło się w jego życiu przydarzyć. Coś, co będzie dowodem, że nie jest jeszcze stary, co da mu poczucie przedłużenia młodości. Młoda partnerka daje taką iluzję" (Michalski, Putek, 2004, s. 85-86). Wraz z upływem czasu może okazać się, że młodą partnerkę nie interesuje seks, ale chęć materialnego 
wyzysku, traktowania starszego mężczyznę jako ojca ${ }^{5}$, opiekuna, przewodnika. Jego atrakcyjność wynika też z posiadanego bogatego doświadczenia życiowego, zgromadzonej rozległej wiedzy (mądrości) i dojrzałości psychicznej.

W literaturze przedmiotu drugą młodość opisuje się jeszcze inaczej, a mianowicie wiąże się ją z chęcią utrzymywania przez współmałżonków aktywności seksualnej, bo pozwala ponownie pomyśleć o swoim życiu erotycznym. Okres ten w ich życiu kojarzy się z możliwością wtórnej integracji małżeńskiej, kiedy dzieci wyprowadzają się z domu, a praca zawodowa nie wymaga już podejmowania szczególnych starań $\mathrm{w}$ robieniu kariery, zaś sprawy antykoncepcji zazwyczaj nie powodują stresu w obszarze życia płciowego. Jest to więc czas, w którym partnerzy mogą poświęcić się własnym sprawom osobistym, ponownie czerpać radość i przyjemność z życia erotycznego, które staje się mniej burzliwe, ale i pogodniejsze.

Z przeprowadzonych wielu badań wynika, że zmniejszenie, a nawet zaniechanie aktywności seksualnej ludzi starych może wynikać z przyczyn fizjologicznych, psychologicznych i kulturowych. Wśród czynników fizjologicznych najczęściej wymienia się zaburzenia na podłożu biomedycznym, np. u mężczyzn - niezdolność osiągnięcia lub utrzymania wzwodu (dysfunkcja erekcji) ${ }^{6}$, i/lub brak fizycznej kondycji niezbędnej do odbycia stosunku, a u kobiet - ból pochwy z powodu zwężenia jej wejścia i zmniejszonego nawilżenia (lubricatio), co prowadzi do nawracającego lub utrzymującego się bólu narządów płciowych podczas stosunku (dyspareunia) ${ }^{7}$, a także choroby (np. nadciśnienie tętnicze, choroba wieńcowa, cukrzyca, zapalenia korzonków nerwowych, nowotwory złośliwe, nietrzymanie moczu, zakażenia układu moczowego, depresja), przebyte operacje oraz długotrwałe przyjmowanie leków (np. przeciwdepresyjnych, nasennych, przeciwnadciśnieniowych) i ich efekty uboczne, mogące zakłócić, ograniczyć lub uniemożliwić życie erotyczne. $Z$ tą kategorią łączy się także niepełnosprawność fizyczna i kalectwo.

Do przyczyn psychologicznych przede wszystkim zalicza się:

- osłabienie lub zaburzenie więzi związku, psychiczne oddalenie się od siebie (np. nieumiejętnie rozwiązane sytuacje kryzysowe, długotrwałe konflikty, zazdrość patologiczna);

${ }^{5}$ Zbigniew Lew-Starowicz sądzi, że uczucie osoby młodej do starszego partnera niekiedy następuje w wyniku niezaspokojenia uczuć w dzieciństwie i traktowania partnera jako substytutu rodzica $(2000$, s. 57).

${ }^{6} \mathrm{Z}$ wymienionych badań wynika, że ten problem w przypadku mężczyzn w wieku 60-69 lat dotyczy - co trzeciego $(34,9 \%)$, zaś w wieku 70 lat i więcej - co drugiego $(55,3 \%)$. Zob. Izdebski (2012, s. 324).

${ }^{7}$ Szczegółowo o tym piszą Leiblum, Segraves (2005, s. 458-516). 
- nuda, monotonia i rutyna życia seksualnego; uboga i statyczna sztuka kochania (ars amandi);

- $\quad$ wieloletni niezdrowy tryb życia (np. nadmierna aktywność, niedobór snu i wypoczynku, przemęczenie fizyczne i psychiczne, życie w stresie, nieprawidłowe odżywanie się, nikotynizm, alkoholizm i inne uzależnienia);

- $\quad$ poczucie zmniejszenia własnej atrakcyjności (np. zmiana wyglądu - siwienie, przerzedzanie i/lub wypadanie włosów, niepewny chód, drżenie rąk; sylwetki - pochylenie postawy ciała; właściwości skóry - wiotczenie, mniejsza elastyczność, suchość, pojawianie się zmarszczek, przebarwień i plam starczych);

- kondycja psychiczna (negatywny bilans dotychczasowego życia wywołuje poczucie porażki i życiowej przegranej, ogólne niezadowolenie z siebie) i kryzysy egzystencjalne (poczucie upływającego czasu, przemijania, rozczarowanie niespełnionymi oczekiwaniami i marzeniami, utrata atrakcyjności erotycznej), co może przenosić się na życie seksualne;

- zmniejszenie zachowań adoracyjnych wobec partnerki ze strony partnera i jego zobojętnienie - „[w]raz z upływem czasu poziom zaangażowania uczuciowego partnerów w związku obniża się, maleje też częstotliwość wzajemnego obdarzania się uwagą i przejawami uczuć - co szczególnie źle znoszą kobiety" (Kaczmarek, 2003, s. 25);

- zmiany w osobowości jednego z partnerów, rozumiane jako obecność trwałych cech charakterologicznych danej osoby i utrwalonych wzorców postępowania, zachowania, relacji $\mathrm{z}$ innymi osobami i funkcjonowania w społeczności (np. osobowość paranoiczna, schizoidalna, dyssocjalna, chwiejna emocjonalnie, histrioniczna, kompulsyjno-obsesyjna, unikająca albo lękliwa, zależna, niedojrzała, ekscentryczna, narcystyczna, bierno-agresywna).

Jeśli chodzi o przyczyny kulturowe są to stereotypy ${ }^{8}$, uprzedzenia, przesądy i negatywne opinie społeczne (np. „seks jest tylko przywilejem młodych ludzi”, „w tym wieku, to już nie wypada” [Kowgier, 2010, s. 169], „celem seksu jest przede wszystkim prokreacja”, „życie seksualne ludzi starszych jest

\footnotetext{
${ }^{8}$ Szczegółowo na ten temat pisze Wawrzyniak (2007, s. 67-76).

${ }^{9} \mathrm{~W}$ badaniach przeprowadzonych przez Zbigniewa Izdebskiego (próba badawcza: 900 mężczyzn i 900 kobiet w wieku 50 lat i więcej) aż 40,5\% respondentów było zdania, że celem seksu w małżeństwie jest przede wszystkim prokreacja (43\% kobiet i 38\% mężczyzn), zaś 38\% nie zgodziło się z tym stwierdzeniem, a $23 \%$ mężczyzn i $16 \%$ kobiet, nie miało zdania na ten temat. Zob. Izdebski (2012, s. 340).
} 
niemoralne" ${ }^{" 10}$, ,ludzie starsi powinni raczej myśleć o dzieciach czy wnukach niż o własnych przyjemnościach” ${ }^{11}$, „życie seksualne prowadzi do utraty życiowej energii”, „seks szkodzi zdrowiu” [Lew-Starowicz, 2000, s. 133]) oraz brak społecznej akceptacji dla zachowań seksualnych człowieka starego ${ }^{12}$ (przyzwolenie społeczne na podejmowanie kontaktów seksualnych przez starą kobietę jest mniejsze niż przez starego mężczyznę).

Ocena życia emocjonalno-seksualnego osób starych jest uzależniona od wzorów kulturowych i zasad religijnych oraz wpływów kultury popularnej, kształtującej obraz seniorów. Kult młodości, pięknego, jędrnego i silnego ciała, fałszowania rzeczywistości, to elementy, które wywierają wpływ na brak tolerancji wobec starości. Te wymienione elementy kultury popularnej przyczyniają się do postrzegania seksualności osób starych jako nieestetyczne, niesmaczne i niemoralne, a tym samym trudne do społecznej akceptacji. Źródło tak negatywnego nastawienia tkwi prawdopodobnie $\mathrm{w}$ niepokoju przed własną starością. Nie da się jednak ukryć, że potrzeba szacunku, bezpieczeństwa, przynależności i spełniania w każdej dziedzinie życia odczuwana jest znacznie silniej przez ludzi starych niż we wcześniejszych okresach życia.

Największym problemem odnoszącym się do seksualności ludzi starych bywa jednak brak partnera. W takiej sytuacji o wiele częściej znajdują się kobiety, bo żyją dłużej od mężczyzn ${ }^{13}$. Śmierć żony/męża albo partnerki/partnera, z powodu której pojawia się często niechęć do współżycia z nową osobą (Stankowska, 2008, s. 15) lub w przypadku kobiet - trudność w znalezieniu partnera, wynikająca z nadumieralności mężczyzn, kulturowego nakazu wyboru partnera starszego od siebie i braku społecznego przyzwolenia na związek starszej kobiety z młodszym mężczyzną (Segraves, Segraves, 1995, s. 88-102).

Na seksualność osób starych wpływa to, w jaki sposób traktowały one seks w młodości. Wyróżnia się dwie grupy seniorów, odmiennie ustosunkowanych

\footnotetext{
${ }^{10}$ Niewielu zwolenników zyskał ten pogląd, bo tylko $14,4 \%$ badanych $(15,4 \%$ kobiet i $13,5 \%$ mężczyzn). 55,5\% zaprzeczyło tej tezie (35,2\% mężczyzn i 26,8\% kobiet w sposób zdecydowany), zaś $16,9 \%$ badanych było niezdecydowanych. Zob. Izdebski (2012, s. 350, 352).

${ }^{11}$ Tego zdania była co czwarta spośród badanych osób. Odmienny pogląd na tę kwestię miało 40,9 (43,2\% mężczyzn i 38,5\% kobiet), zaś niezdecydowanych było $21 \%$. Zob. Izdebski (2012, s. $353-354,356)$.

${ }^{12}$ Tę sytuację Andrzej Jaczewski określa jako „irracjonalna złośliwość” (2006, s. 39).

${ }^{13}$ W 2017 r. średni czas trwania życia dla kobiet wynosił 81,8 lat, a dla mężczyzn 73,9 lat (Rocznik Demograficzny 2019, s. 502). W państwach wysoko rozwiniętych wskaźnik ten z roku na rok wyrównuje się, co wynika z większej dynamiki wydłużania się życia wśród mężczyzn niż wśród kobiet.
} 
do tej kwestii. Do pierwszej należą osoby, które w ciągu całego życia charakteryzowały się wysoką aktywnością seksualną i także w okresie starości przejawiają zainteresowanie tą sferą życia, w niewielkim zakresie tylko je redukując. Są to osoby o bardzo silnym popędzie i dla których seks ma duże znaczenie, poświęcają tej aktywności wiele uwagi i czasu.

Druga grupa to osoby, dla których seks nigdy nie był ważnym elementem życia i ich aktywność seksualna zawsze była niewielka. Seks nigdy nie stanowił dla nich większej wartości. Są to osoby oziębłe, dla których wiek podeszły, starczy czy sędziwy i stereotyp aseksualnej starości - stwarzają okazję do skrywania niechęci do tej aktywności. Ludzie ci stosunkowo łatwo godzą się na zaniechanie współżycia seksualnego (Jaczewski, 2006, s. 39).

Bardzo optymistyczny obraz współczesnych seniorów przedstawiła Danuta Broniszewska:

Seniorzy nie czują się staro. Wprost przeciwnie. Obie płcie poszukują w internecie nowych partnerów, dyskutują o seksie i miłości. O tym, że szukają nowych doznań, świadczy ogromny wzrost pozwów o rozwód. W przypadku kobiet po pięćdziesiątce - o $28 \%$, a mężczyzn po sześćdziesiątce - aż o 39\%. Pięćdziesięciolatki, uwolnione od wychowania dzieci, pracy zawodowej i pigułki antykoncepcyjnej, chętnie romansują. Sześćdziesięciolatkowie dzięki viagrze i internetowi czują się pewniej niż kiedykolwiek. Pokolenie trzeciego wieku chce używać życia (Wroniszewska, 2006, s. 71).

Natomiast Zbigniew Izdebski zwraca uwagę na przemianę w zachowaniach erotycznych Polaków. Wszak stajemy się bardziej śmiali w łóżku. Najbardziej uderzająca zmiana dotyczy seksu ludzi po 50. roku życia i starszych, charakteryzuje nas „duży stopień otwartości w ujawnianiu informacji dotyczących własnej seksualności (zachowań, potrzeb, deficytów, lęków, doświadczeń)" (Izdebski, 2012, s. 110).

Namiętność i pożądanie seksualne - jak wynika $\mathrm{z}$ wielu przeprowadzonych badań - są początkowo bardzo silne, ale znacznie słabną z upływem lat (Acker, Davis, 1992, s. 21-50; Aron, Aron, 1994, s. 131-152). Jeśli namiętność nieuchronnie słabnie, to dlaczego ludzie trwają w wieloletnich związkach? Niekiedy małżonkowie twierdzą, że są ze sobą z powodu dzieci, ale często podają, że długoletni partnerzy stają się nieodłączną częścią ich życia, a w miarę, jak namiętność przygasa, to wzmaga się uczucie zaangażowania i intymności. W okresie starości ważnym staje się bliskość, wzajemna akceptacja, poczucie bezpieczeństwa, wsparcie, bycie ze sobą.

Zbigniew Lew-Starowicz, na podstawie badań przeprowadzonych w wielu krajach, wymienił cztery funkcje seksu w okresie starości: zdrowotną, integra- 
cyjną, rekreacyjną i felicytologiczną. Funkcja zdrowotna polega na promowaniu zdrowego stylu życia, docenianiu wartości aktywności seksualnej jako działania prozdrowotnego, bo osoby aktywne seksualnie starzeją się wolniej, charakteryzują się lepszym stanem zdrowia i większą odpornością organizmu. Wszak aktywność seksualna to forma treningu szeregu narządów i układów (mięśniowego, nerwowego, krążeniowego, hormonalnego), wpływa pobudzająco na receptory i neuroprzekaźniki w centralnym układzie nerwowym, sprzyja zdrowiu psychicznemu. Funkcja integracyjna sprowadza się do podtrzymywania bliskich więzi i pełnej harmonii między partnerami, zaspokojenia wszelkich potrzeb uczuciowych, a także samorealizacji - wzrostu i rozwoju własnej osoby, wynikających z własnych możliwości i dążeń. Funkcja rekreacyjna jest ukierunkowana na docenianie znaczenia relaksu: współżycie seksualne jest źródłem odprężenia oraz rozładowania napięć, obciążeń i przeciążeń życiowych. Funkcja felicytologiczna jest związana z doznaniem przyjemności i szczęścia oraz zmniejszeniem lub wyeliminowaniem agresywności, a także innych negatywnych uczuć (Lew-Starowicz, 2000, s. 41).

Na uwagę zasługuje fakt, że specjaliści (np. lekarze, psycholodzy) nie zajmują się problemami seksualnymi osób starych. Zazwyczaj ich nie doceniają, a nawet ignorują. Wiele dysfunkcji seksualnych ${ }^{14}$ u ludzi starych jest prawie nie leczona. Jednak w ostatnim czasie rozwinęła się dziedzina seksuologii, zwana gerontoseksuologią, której jednym z celów jest usprawnianie życia seksualnego osób starych (Lew-Starowicz, 2004, s. 17). Pod wpływem rozmaitych leków, zabiegów rehabilitacyjnych, praktycznych wskazówek możliwe staje się udzielenie skutecznej pomocy i utrzymanie aktywności seksualnej przez wiele lat życia, a to z kolei oddziałuje pozytywnie na zdrowie psychiczne oraz trwałość związków formalnych i nieformalnych.

\section{Podsumowanie}

Obraz seksualności osób starych jest dość złożony i zróżnicowany. Wraz z wiekiem maleje aktywność seksualna, po wygaśnięciu czy obniżeniu się poziomu hormonów płciowych, a także faktycznych możliwości. Maleje też niekiedy

\footnotetext{
${ }^{14}$ Szczegółowo na temat leczenia zaburzeń seksualnych pisze Lew-Starowicz (2000, s. $159-180)$.
} 
zainteresowanie seksem, ale nie zanika. Aczkolwiek w okresie starości wzrasta potrzeba więzi, bliskości, wzajemnego zrozumienia, wzajemnej pomocy i czułości (Izdebski, 2012, s. 379; Jaczewski, 2006, s. 40), to jednak nie usuwa potrzeby rozładowania popędu, w jakimkolwiek natężeniu byłby on odczuwany i jak wstydliwie skrywany. Poddane analizie badania ewidentnie przeczą potocznym opiniom, jakoby starość radykalnie eliminowała te potrzeby. Przekonanie to $\mathrm{w}$ grupach ludzi młodych zakotwiczone jest $\mathrm{w}$ utartych stereotypach. Wynika ono również z postaw ludzi starych, którzy na tę sferę swego życia spuścili zasłonę milczenia - z obawy przed utratą wizerunku osoby dostojnej, żyjącej zgodnie ze wzorami kulturowymi godnej starości (matrony, seniora rodu) i narażeniem się na krzywdzące etykiety (np. dzidzia piernik, obleśny erotoman). Bariery te są $\mathrm{z}$ trudem przełamywane, o czym świadczy to, że osoby stare ostentacyjnie je naruszające i demonstrujące swoją seksualność, ciągle jeszcze są $\mathrm{w}$ opinii społecznej traktowane $\mathrm{z}$ awersją. Wydaje się więc, że ten aspekt zagadnienia powinien być poddany wnikliwszym badaniom zarówno ze względów poznawczych, jak i potrzeby opracowania wskazań dla praktyki edukacyjnej.

Innym, ale równie marginalnie traktowanym zagadnieniem jest problem sposobów zaspokajania popędu płciowego przez starzejących się singli. Dotyczy to jednocześnie osób heteroseksualnych, jak i homoseksualnych. Są one zdecydowanie różne od tych, w przedstawionych tu badaniach. Polegają na okazjonalnych, przygodnych kontaktach albo też płatnych usługach erotycznych. Charakteryzuje je: przelotność, relacje raczej bezosobowe i bez zaangażowania emocjonalnego. Problemy te, jeśli są podejmowane, to w kontekście prostytucji, a więc od strony usługodawcy z zupełnym pominięciem motywacji takiego wyboru, przeżyć i zabiegów usługobiorcy.

Nie ulega wątpliwości, że czymś istotnym stają się wskazania dla praktyki pedagogicznej: potrzeba nowego spojrzenia na starość człowieka, zmieniającego tradycyjne schematy postrzegania ludzi starych, które kontestują ich prawo do związków i doznawania satysfakcji seksualnej w późnym wieku; upowszechniania wiedzy o seksualności ludzi starych, kreowania w środowisku społecznym i relacjach międzypokoleniowych postaw akceptujących ich aktywność seksualną, promowania aktywnego i zdrowego stylu życia; udostępniania usług w zakresie diagnozy i leczenia rozmaitych zaburzeń seksualnych oraz poprawy aktywności seksualnej; odpowiedniego przygotowania do starości, kształtowania u ludzi młodych pozytywnego obrazu starości, rozwijania w nich aspiracji i dążeń istotnych w ostatnim okresie życia. 


\section{References}

Acker, M., Davis, M. H. (1992). Intimacy, Passion and Commitment in Adult Romantic Relationships. A Test of the Triangular Theory of Love. Journal of Social and Personal Relationships, t. 9, nr 1.

Aron, A., Aron, E. N. (1994). Love. W: A. L. Weber, J. H. Harvey (red.), Perspectives on Close Relationships. Boston: Allyn \& Bacon.

Chmura-Rutkowska, I., Ostrouch, J. (2007). Mężczyźni na przełęczy życia. Studium socjopedagogiczne. Kraków: Oficyna Wydawnicza Impuls.

Czupryn, A. (2008). Ślub po sześćdziesiq̨tce: To może być miłość. Pobrano z: http://www.polskatimes.pl/artykul/50984,slub-po-szescdziesiatce-to-moze-byc-milosc,3,id,t,sa.html (otwarty 4.04.2019).

Dębski, R. (2014). Andropauza, czyli męskie przekwitanie. Pobrano z: http://www.poradnikzdrowie.pl/zdrowie/choroby-meskie/andropauza-czyli-meskie-przekwitanie_33540.html (otwarty 4.04.2019).

Goodwin, J. S., Hunt, W. C., Key, Ch. R., Samet, J. M. (1987). The Effect of Marital Status on Stage, Treatment, and Survival of Cancer Patients. Journal of the American Medical Association, nr 258. Pobrano z: https://www.ncbi.nlm.nih.gov/pubmed/3669259 (otwarty 2.04.2019).

Hatfield, E., Rapson, R. L. (1996). Love and Sex: Cross-Cultural Perspectives. Boston: Allyn \& Bacon. Izdebski, Z. (2012). Seksualność Polaków na progu XX wieku. Studium badawcze. Kraków: Wydawnictwo Uniwersytetu Jagiellońskiego.

Jaczewski, A. (2006). Seks osób w wieku podeszłym. W: J. Rzepka (red.), Problematyka osób w wieku starszym. Materiały z III Ogólnopolskiego Seminarium Naukowego. Mysłowice: Górnośląska Wyższa Szkoła Pedagogiczna im Kardynała Augusta Hlonda.

Kaczmarek, J. (2003). Seksualne i nieseksualne motywy podejmowania aktywności seksualnej. Małżeństwo i Rodzina, t. 2, nr 3 (7).

Kałużna, D. (2010). Nowożeńcy w „późnym wieku” w Polsce. W: D. Kałużna, P. Szukalski (red.), Jakość życia seniorów w XXI wieku z perspektywy polityki społecznej. Łódź: Uniwersytet Łódzki.

Kaprio, J., Koskenvuo, M., Rita, H. (1987). Mortality after Bereavement. A Prospective Study of 95647 Widowed Persons. American Journal of Public Health, t. 77, nr 3.

Kowgier, A. (2010). Życie intymno-emocjonalne osób starszych. Kraków: Oficyna Wydawnicza Impuls.

Leiblum, S. R., Segraves ,R. T. (2005). Terapia seksualna osób w podeszłym wieku. W: S. R. Leiblum, R. C. Rosen (red.), Terapia zaburzeń seksualnych, tłum. D. Golec, A. Rozwadowska, J. West, E. Wojtych. Gdańsk: Gdańskie Wydawnictwo Psychologiczne.

Lew-Starowicz, Z. (2000). Seks w jesieni życia. Warszawa: Dom Wydawniczy Bellona.

Lew-Starowicz, Z. (2004). Seks w jesieni życia. Matżeństwo i Rodzina, t. 3, nr 3 (11).

Michalski, A., Putek, I. (2004). Rozmowy o przemijaniu. Praktyczny przewodnik po wieku dojrzatym: rodzina, praca, seks, zdrowie, rozm. przepr. M. Kwiatkowska. Warszawa: Edipresse Polska; Poznań: Zysk i S-ka.

Muszyński, M. (2007). Rozważania dotyczące aktywności seksualnej osób w trzecim wieku. Gerontologia Społeczna, nr 1 (2). 
Pietkiewicz, B. (2008). Urok siwych gołąbków. Polityka, nr 34 (2668).

Podogrodzka, M. (1992). Zróżnicowanie umieralności według stanu cywilnego. Studia Demograficzne, nr 3 (109).

Rocznik Demograficzny 2019. Warszawa: Główny Urząd Statystyczny.

Segraves, R. T., Segraves, K. B. (1995). Human sexuality and aging. Journal of Sex Education and Therapy, t. 21, nr 2.

Stankowska, I. (2008). Funkcjonowanie seksualne człowieka w okresie starzenia się i starości. Przegląd Terapeutyczny, nr 4. Pobrano z: http://www.ptt-terapia.pl/wp-content/uploads/2011/ 06/Stankowska.pdf (otwarty 2.04.2019).

Szlendak, T. (2011). Socjologia rodziny. Ewolucja, historia, zróżnicowanie. Warszawa: Wydawnictwo Naukowe PWN.

Szukalski, P. (2004). Kohabitacja w Polsce. W: W. Warzywoda-Kruszyńska, P. Szukalski (red.), Rodzina $w$ zmieniającym się społeczeństwie polskim. Łódź: Wydawnictwo Uniwersytetu Łódzkiego.

Szukalski, P. (2006). Wdowieństwo w starszym wieku w Polsce. Gerontologia Polska, t. 14, nr 2.

Szukalski, P. (2007). Zróżnicowanie poziomu umieralności a stan cywilny. Wiadomości Statystyczne, t. 52, nr 5 (552).

Szukalski, P. (2013). Małżeństwo: początek i koniec. Łódź: Wydawnictwo Uniwersytetu Łódzkiego.

Szukalski, P. (2014). Małżeństwa zawierane w starszym wieku - szkic demograficzny. W: A. A. Zych (red.), Starość darem, zadaniem i wyzwaniem. Sosnowiec-Dąbrowa Górnicza: Stowarzyszenie Przyjaciół Domu Pomocy Społecznej „Pod Dębem”.

Vetulani, J. (2015). Na młodość - wino, głodówka i seks, rozm. przepr. M. Harland. Gazeta Wyborcza, nr 107 (8440).

Wawrzyniak, J. (2007). Funkcjonowanie stereotypu starości w społeczeństwie. Gerontologia Spoteczna, nr 1 (2).

Wroniszewska, D. (2006). Era miłości pragmatycznej. Angora - Peryskop, t. 17, nr 37 (847).

Żelazińska, A. (2015). Single z odzysku. Polityka, nr 29 (3018). 